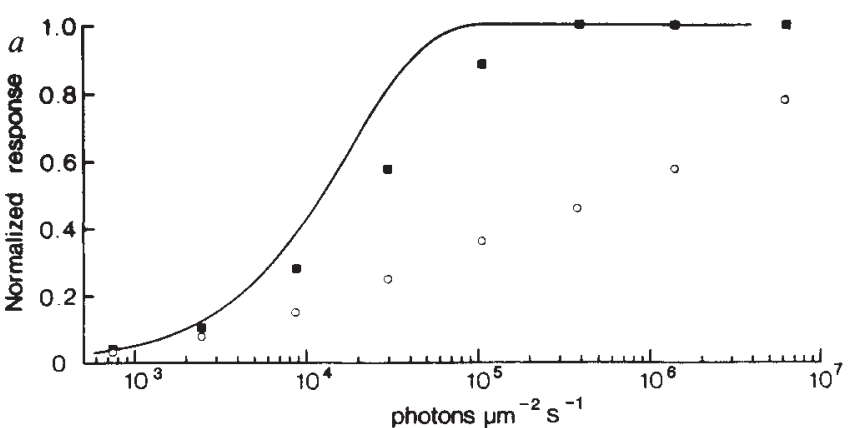

$b$

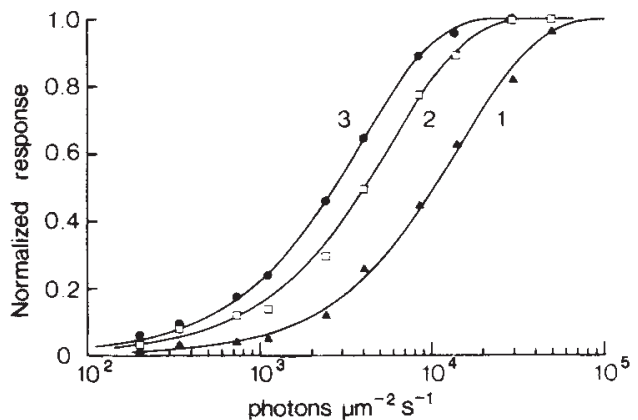

Fig. 4 Response-intensity plots obtained from the cone experiments of Fig. 3. All response amplitudes have been normalized against corresponding dark currents (see Fig. 3 legend). $a$, Response amplitudes were measured at transient peak ( $\mathbf{\square})$ and at the end of the light step $(O) . b$, Response amplitudes were measured at $0.2 \mathrm{~s}(\boldsymbol{\Delta})$ and $0.4 \mathrm{~s}(\square)$ after light onset, and at steady-state level (O). The smooth curves were all drawn according to equation (1).

position on the light intensity axis, provides convincing evidence that the underlying single-photon effects are invariant with light intensity. Four other experiments gave similar conclusions.

Essentially the same results were obtained from cones. The response-intensity family in Fig. $3 a$ was obtained from a cone in normal Ringer solution, whereas that in Fig. $3 b$ was obtained from a cone in test solution. Again, the prominent relaxations shown in the control responses were absent in the test solution. Measurements made from the experiments in Fig. 3 are shown in Fig. 4. In Fig. 4a, the normalized response amplitudes at both the transient peak and at the end of the light step in Fig. $3 a$ are plotted against light intensity; in both cases the experimental points fall substantially below the curve drawn from equation (1), indicating light adaptation. We found the same in four other experiments. In these experiments we unfortunately could not make meaningful measurements of the response amplitude at times earlier than the transient peak because the rather slow membrane time constant in cones limits the rate of rise of the response. In Fig. $4 b$, the relations between response amplitude and light intensity from Fig. $3 b$ are plotted at times of $0.2 \mathrm{~s}$ and $0.4 \mathrm{~s}$ after light onset, and at the steady-state level. As for rods under the same conditions, the relations can be fitted by the theoretical relation assuming no light adaptation. Again, the position of curve 3 , which fits the steady-state relation, has been calculated from the normalized amplitude and the integration time of the response of a cell to a dim flash (inset of Fig. $3 b$ ). The agreement between prediction and experiment is excellent, with respect to both the form of the relation and its position on the abscissa. Six other experiments gave much the same results.

The results described here strongly suggest that the $\mathrm{Ca}^{2+}$ feedback underlies practically all light adaptation exhibited by retinal rods and cones. As mentioned earlier, this $\mathrm{Ca}^{2+}$ feedback arises from a decline of free $\mathrm{Ca}^{2+}$ in the receptor's outer segment during illumination, which occurs roughly with a time constant of $0.5 \mathrm{~s}$ in rods ${ }^{9,11}$ and $0.1 \mathrm{~s}$ in cones ${ }^{12,13}$. The faster $\mathrm{Ca}^{2+}$ decline in cones is therefore consistent with the more rapid development of light adaptation in these cells, as shown above. The mechanism by which $\mathrm{Ca}^{2+}$ affects the cGMP level is still not entirely clear at present. At least part of this action appears to arise from an inhibitory effect of $\mathrm{Ca}^{2+}$ on guanylate cyclase, which synthesises cGMP ${ }^{18-21}$. In addition, $\mathrm{Ca}^{2+}$ may stimulate the cGMP phosphodiesterase, directly or indirectly ${ }^{10,22,23}$. Finally, note that, although amphibian rods and cones both exhibit light adaptation, only the cones of the primate retina show this phenomenon ${ }^{17}$. A clue to the puzzle why primate rods do not light-adapt may be derived from examining the $\mathrm{Ca}^{2+}$ feedback in these cells.

We thank Dr L. W. Haynes for comments. This work was supported by a grant from the US National Eye Institute.

Received 11 May; accepted 24 May 1988

1. Pugh Jr, E. N. \& Cobbs, W. H. Vision Res. 26, 1613-1643 (1986)

2. Stryer, L. A. Rev. Neurosci. 9, 87-119 (1986)

3. Yau, K.W. \& Baylor, D. A. A. Rev. Neurosei 12, (in the press).

4. Yau, K.-W. \& Baylor, D. A. A. Rev. Neurosci. 12, (in the pro

5. Hodgkin, A. L., McNaughton, P. A. \& Nunn, B. J. J. Physiol, Lond. 358, 447-468 (1985).

6. Cohen, A. I., Hall, I. A. \& Ferrendelli, J. A. J. gen. Physiol. 71, 595-612 (1978).

7. Kilbride, P. J. gen. Physiol. 75, 457-465 (1980).

8. Woodruff, M. L. \& Fain, G. L. J. gen. Physiol. 80, 537-555 (1982)

9. Yau, K.-W. \& Nakatani, K. Nature 313, 579-582 (1985)

10. Torre, V., Matthews, H. R. \& Lamb, T. D. Proc, natn. Acad. Sci. U.S. A. 83, 7109-7113 (1986).

11. Nakatani, K. \& Yau, K.-W. J. Physiol, Lond. 395, 695-729 (1988).

12. Cobbs, W. H. \& Pugh Jr., E. N. Biophys. J. 49, 280a (1986)

13. Yau, K.-W. \& Nakatani, K. Biophys. J. 53, 473a (1988)

14. Yau, K.-W., McNaughton, P. A. \& Hodgkin, A. L. Nature 292, 502-505 (1981)

15. Hodgkin, A. L., McNaughton, P. A., Nunn, B. J. \& Yau, K.W. J. Physiol, Lond. 350, 649-680 (1984).

16. Lamb, T. D., McNaughton, P. A. \& Yau, K.-W. J. Physiol, Lond. 319, 463-486 (1981)

17. Baylor, D. A., Nunn, B. J. \& Schnapf, J. L. J. Physiol, Lond. 357, 575-607 (1984)

18. Lolley, R. N. \& Racz, E. Vision Res. 22, 1481-1486 (1982).

19. Pepe, I. M., Panfoli, 1. \& Cugnoli, C. FEBS Lett. 203, 73-76 (1986)

20. Koch, K.-W. \& Stryer, L. Biophys. J. 53, 388a (1988)

21. Hodgkin, A. L. \& Nunn, B. J. J. Physiol, Lond. (in the press).

22. Robinson, P. R., Kawamura, S., Abramson, B. \& Bownds, M. D. J. gen. Physiol 76, 631-645 (1980).

23. Hodgkin, A. L. in Proceedings of First Retina Research Foundation Symposium (ed. Lam, D. M. K.) (Portfolio Publishing, Woodlands, Texas, in the press).

24. Harosi, F. J gen. Physiol 66, 357-382 (1975)

24. Harosi, F. J gen. Physiot 66, 357-382 (1975). 481-528 (Springer, New York, 1972).

26. Liebman, P. A. \& Entine, G. Vision Res. 8, 761-775 (1968).

27. Attwell, D., Werblin, F. S. \& Wilson, M. J. Phvsiol, Lond. 328, 259-283 (1982)

\section{Picomolar concentrations of lead stimulate brain protein kinase $\mathrm{C}$}

\author{
Jasna Markovac \& Gary W. Goldstein \\ Departments of Pediatrics and Neurology, \\ University of Michigan Medical School, Ann Arbor, \\ Michigan 48109-0570, USA
}

Recent growth studies in children suggest that there is no threshold for adverse effects from the universal exposure to inorganic lead ${ }^{1}$. The biochemical mechanisms mediating low-level toxicity are unclear, but in several biological systems, lead alters calciummediated cellular processes ${ }^{2,3}$ and may mimic calcium in binding to regulatory proteins ${ }^{4}$. Here we present evidence that lead stimulates diacylglycerol-activated calcium and phospholipid-dependent protein kinase, protein kinase $\mathrm{C}$, partially purified from rat brain. Picomolar concentrations of lead are equivalent to micromolar calcium in kinase activation, so this regulatory enzyme is sensitive to the lead levels expected from current environmental exposure.

Lead poisoning results in permanent brain damage ${ }^{5}$, highlevel exposure during childhood causing distinct neurological problems and irreversible mental retardation ${ }^{6}$. Exposure even to subclinical levels of lead produces intelligence deficits, poor academic achievement ${ }^{7}$, hyperactivity, and deficient fine motor control $^{8}$, as well as short stature and decreased weight ${ }^{1}$. Depend- 


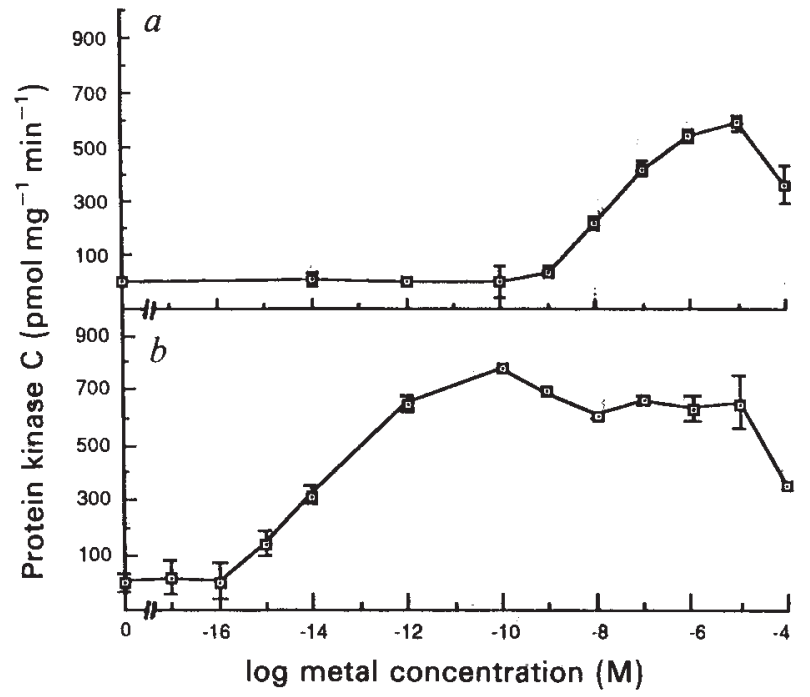

Fig. 1 Dose-dependent stimulation of protein kinase $\mathrm{C}$ by calcium (a) and lead (b).

Methods. Protein kinase $\mathrm{C}$ activity was partially purified from freshly isolated brain of adult Sprague-Dawley rats. The brains were washed and homogenized in buffer containing $20 \mathrm{mM}$ HEPES, $p \mathrm{H}$ 7.5, $2 \mathrm{mM}$ EDTA, $2 \mathrm{mM}$ EGTA, 0.25 $\mathrm{M}$ sucrose and $10 \mathrm{mM} \mathrm{2-mercaptoethanol,} \mathrm{and} \mathrm{then} \mathrm{centrifuged} \mathrm{for} 1 \mathrm{~h}$ ăt $5,000 \mathrm{~g}$. The resulting supernatant fraction was loaded on to a prewashed DE52 ion-exchange column. The column was washed extensively with homogenization buffer and the kinase actlvity was eluted with $0.2 \mathrm{M} \mathrm{NaCl}$ in the above buffer. The fractions containing protein kinase $\mathrm{C}$ activity were pooled and used in subsequent experiments. Protein kinase activity was assayed by a modification of the procedure described by Takai et al. ${ }^{13}$, measuring the incorporation of radiolabel from $\left[{ }^{32} \mathrm{P}\right] \mathrm{ATP}$ into endogenous cytosolic protein and exogenous lysine-rich histones. In $250 \mu \mathrm{l}$ total volume, the standard reaction mixture contained $20 \mathrm{mM}$ Tris- $\mathrm{HCl}(p \mathrm{H} \mathrm{7.4}), 5 \mathrm{mM}$ $\mathrm{MgCl}_{2}, 5 \mu \mathrm{g}$ phosphatidylserine, $5 \mu \mathrm{g}$ 1,2-diolein (or equivalent volume of double distilled $\left.\mathrm{H}_{2} \mathrm{O}\right), 20 \mu \mathrm{g}$ lysine-rich histones, $0.2 \mathrm{nmol}$ ATP, $2 \mu \mathrm{Ci}\left[{ }^{32} \mathrm{P}\right] \mathrm{ATP}\left(4,000 \mathrm{Ci} \mathrm{mmol}^{-1}, \mathrm{ICN}\right)$, and a specified concentration of $a, \mathrm{CaCl}_{2}$ or $b$, lead acetate. The reaction was initiated by addition of $100 \mu \mathrm{l}$ pooled kinase fraction containing 1-3 $\mu \mathrm{g}$ protein, incubated for $5 \mathrm{~min}$ at $30^{\circ} \mathrm{C}$ and terminated by addition of $75 \mu 112 \mathrm{M}$ glacial acetic acid. Phosphorylated proteins were collected by adsorption on Whatman P81 phosphocellulose papers. The filters were washed once in $30 \%$ acetic acid, twice in $15 \%$ acetic acid and finally in acetone. The radioactivity was quantitated by Cerenkov counting and protein content determined by the method of Bradford ${ }^{29}$. Protein kinase activity was calculated as the difference in the activity in the presence and absence of 1,2-diolein. Values plotted are the means of three replicates \pm s.e.m. Data points without error bars represent s.e.m. $<$ $5 \%$. Equivalent results were obtained in three separate experiments.

ing on the criteria used to define excessive exposure, as many as $9-25 \%$ of pre-school children are at risk for adverse effects from low levels of lead ${ }^{9}$. The biochemical mechanisms of lead toxicity are unknown, but at least some of its deleterious effects are attributed to interference with calcium-mediated proces$\operatorname{ses}^{2,3}$, and lead is known to alter the metabolism of calcium in several tissues ${ }^{10}$.

Protein kinase $\mathrm{C}$ is a calcium- and phospholipid-dependent enzyme that can mediate cellular proliferation, differentiation and function by phosphorylating critical regulatory proteins ${ }^{11}$. This kinase is activated by a diacylglycerol second messenger produced by receptor-mediated hydrolysis of inositol phospholipids. Inositol trisphosphate is another product of this hydrolysis that causes the release of calcium from the endoplasmic reticulum ${ }^{12}$. We chose to investigate the effect of lead on protein kinase $\mathrm{C}$ because it is regulated by calcium ${ }^{13}$ and is critical in the control of cellular signal transduction ${ }^{11}$.

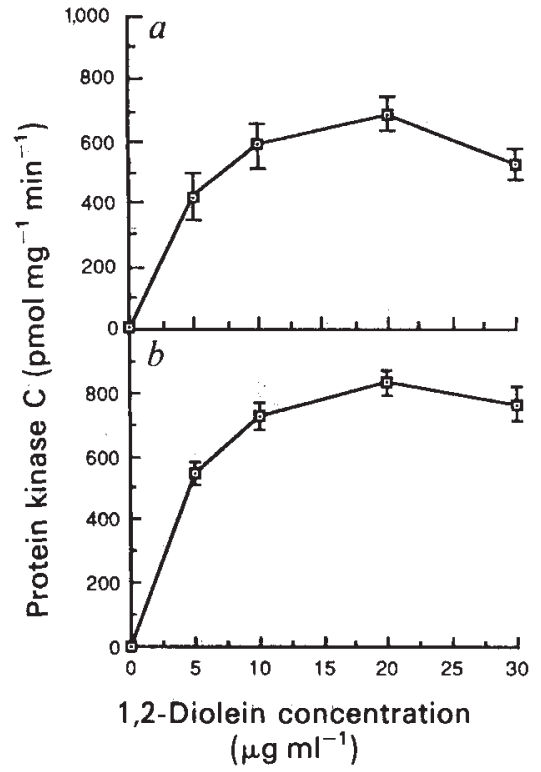

Fig. 2 Diacylglycerol-dependent activation of protein kinase C in the presence of calcium or lead. Diacylglycerol requirements of protein kinase $C$ were tested in the presence of $a, 10^{-5} \mathrm{M}$ calcium, or $b, 10^{-10} \mathrm{M}$ lead. $\mathrm{CaCl}_{2}$ or lead acetate at the appropriate concentration was added to the standard reaction mixture and the kinase activity assayed in the presence of various amounts of 1,2-diolein $\left(0-30 \mu \mathrm{g} \mathrm{ml}^{-1}\right)$. Values plotted are the means of three replicates \pm s.e.m. Data points without error bars represent s.e.m. $<$ $5 \%$. Equivalent results were obtained in three separate experiments.

Protein kinase $\mathrm{C}$ was partially purified from fresh rat brain (see Fig. 1 legend for methods and assay conditions). Enzyme activity was recovered by salt elution using ion exchange chromatography and measured as diacylglycerol-specific incorporation of radiolabel from $\left[{ }^{32} \mathrm{P}\right] \mathrm{ATP}$ into exogenous lysinerich histones in the presence of lead or calcium. Figure 1 illustrates the stimulation of protein kinase $C$ as a function of calcium (Fig. 1a) and lead (Fig. 1b) concentration. There was no detectable diacylglycerol-and phospholipid-dependent protein kinase activity in the absence of either cation. Kinase activity increased with increasing calcium concentration, with a threshold in the nanomolar range, peaked at $10^{-5} \mathrm{M}$, and then declined. This decrease in activity reflects a reduced affinity of protein kinase $\mathrm{C}$ for diacylglycerol at higher calcium concentrations. A similar decline was observed in the presence of lead at concentrations $>10^{-5} \mathrm{M}$, suggesting an analogous mechanism for interaction with protein kinase $\mathrm{C}$. Protein kinase activity was stimulated by much lower concentrations of lead, with a threshold in the picomolar range and a peak at $10^{-10} \mathrm{M}$. We compared the requirement for diacylglycerol of the kinase activity stimulated by lead at $10^{-10} \mathrm{M}$ with the calcium-stimulated enzyme. Using varying amounts of 1,2 -diolein $\left(0-30 \mu \mathrm{g} \mathrm{ml}^{-1}\right)$, the kinetic plots generated from these experiments were quite similar in general shape (Fig. 2). There was no detectable phospholipid-dependent protein kinase activity with either cation in the absence of diolein. Comparison of the time course for protein kinase $\mathrm{C}$ activation by either lead or calcium also indicates a similar degree of protein kinase $\mathrm{C}$-mediated substrate phosphorylation by $10^{-10} \mathrm{M}$ lead and by $10^{-5} \mathrm{M}$ calcium (data not shown). In the presence of either cation, the reaction was linear up to $10 \mathrm{~min}$ incubation at $30^{\circ} \mathrm{C}$. To determine whether the picomolar threshold for the activation of protein kinase $\mathrm{C}$ is specific to lead or is merely a ubiquitous effect of heavy metals, we tested several different cations and heavy metals for their ability to stimulate the kinase activity. As shown in Table 1, only lead was able to activate this enzyme at $10^{-10} \mathrm{M}$ to a degree comparable with 
Table 1 Activation of protein kinase $\mathrm{C}$ by heavy metals

$\begin{array}{lc}\text { Condition } & \begin{array}{c}\text { Protein kinase } \\ \left(\mathrm{pmol} \mathrm{mg}^{-1} \mathrm{~min}^{-1}\right)\end{array} \\ \mathrm{No} \text { addition } & 11.8 \pm 45.3 \\ \mathrm{~Pb} & 550.1 \pm 77.3 \\ \mathrm{Ca} & 43.8 \pm 70.8 \\ \mathrm{Hg} & 17.9 \pm 44.1 \\ \mathrm{Cu} & 22.4 \pm 40.9 \\ \mathrm{Zn} & 47.3 \pm 10.2 \\ \mathrm{Ba} & 34.9 \pm 14.3 \\ \mathrm{Mb} & 38.8 \pm 16.4 \\ \mathrm{Sr} & 33.9 \pm 6.7 \\ \mathrm{Co} & 9.5 \pm 20.4 \\ \mathrm{Fe} & 11.6 \pm 57.7 \\ \mathrm{Mn} & 37.2 \pm 33.0 \\ \mathrm{Ni} & 8.4 \pm 54.9\end{array}$

Each metal was tested in the standard reaction mixture at a concentration of $10^{-10} \mathrm{M}$ as a substitute for $\mathrm{CaCl}_{2}$ in the activation of protein kinase C. Values represent means of three determinations \pm s.e.m. Lead showed statistically significant activation of protein kinase $C$ at $P<0.002$ using a one-tailed $t$-test with Bonferroni correction for multiple comparisons ${ }^{28}$. All other metals tested were not significantly different from the untreated control at $P \leq 0.05$.

micromolar calcium. Different lead salts at picomolar concentrations were also assayed for ability to activate the enzyme to verify that the lead cation itself was responsible for the stimulation of protein kinase $C$. The lead salts were all found to be equally effective, and sodium acetate gave us no detectable diacylglycerol-activated, phospholipid-dependent protein phosphorylation (see Table 2).

Protein kinase $C$ phosphorylates various critical cell membrane and transport proteins ${ }^{11}$, and is thus a major site for regulation of cellular growth and differentiation. The enzyme is thought to be the cellular receptor for tumour-promoting phorbol esters ${ }^{14}$. Mapping of these receptors and studies with monoclonal antibodies indicate that protein kinase $\mathrm{C}$ is widely distributed in the brain ${ }^{15,16}$. Using highly immunospecific polyclonal antibodies, the enzyme in the brain has been localized largely to presynaptic terminals ${ }^{17}$. This finding is consistent with an important role for protein kinase $\mathrm{C}$-mediated protein phosphorylation in the regulation of presynaptic function ${ }^{17}$. Lead accumulates in the synaptic regions of the brain and is thought to interfere with the release of neurotransmitters ${ }^{18,19}$. Here we present evidence that picomolar concentrations of lead activate partially purified rat brain protein kinase $\mathrm{C}$ to an extent similar to that stimulated by micromolar calcium. At $10^{-10} \mathrm{M}$ lead, the requirement of the protein kinase for diolein was similar to that found with $10^{-5} \mathrm{M}$ calcium, the standard condition for assay of protein kinase $C$. This suggests that lead mimics calcium in the activation of protein kinase $C$.

Nishizuka and coworkers investigated the effects of several heavy metals on this enzyme and found that at micromolar concentrations some can activate protein kinase $C^{20}$, but lead was not included in these investigations. We find that the response at picomolar levels was specific for lead (Table 1). Several studies report other lead-induced biochemical effects. At micromolar concentrations, lead can reversibly inhibit $\left(\mathrm{Na}^{+}+\right.$ $\mathrm{K}^{+}$)-ATPase activity ${ }^{21}$. At concentrations $>10^{-5} \mathrm{M}$ lead interferes with acetylcholine metabolism, a calcium-dependent pro$\operatorname{cess}^{22}$. Over the same concentration range, this toxicant also inhibits the calcium-mediated $\alpha$-adrenergic regulation of pyruvate kinase activity ${ }^{23}$. Earlier work has shown that micromolar lead activates calmodulin-sensitive phosphodiesterase and promotes potassium loss from erythrocytes by replacing calcium ${ }^{24}$. We investigated the effects of lead on calcium/calmodulindependent protein kinase activity and found a stimulatory effect at $10^{-5} \mathrm{M}$ but no activation at $10^{-10} \mathrm{M}$ (data not shown). The activation of protein kinase $\mathrm{C}$ by picomolar levels of lead is
Table 2 Effect of lead salts and sodium acetate on protein kinase activity

\begin{tabular}{|c|c|}
\hline Salt & $\begin{array}{l}\text { Protein kinase } \mathrm{C} \text { activity } \\
\quad\left(\mathrm{pmol} \mathrm{mg} \mathrm{min}^{-1}\right)\end{array}$ \\
\hline None & $\mathrm{ND}^{*}$ \\
\hline Lead acetate & $610.1 \pm 47.2$ \\
\hline Lead chloride & $672.0 \pm 64.6$ \\
\hline Lead citrate & $635.7 \pm 78.8$ \\
\hline Sodium acetate & ND \\
\hline
\end{tabular}

Protein kinase $\mathrm{C}$ was activated by the addition of the specified compound to the standard reaction mixture at $10^{-10} \mathrm{M}$. Values represent means of three determinations \pm s.e.m. All three lead salts showed statistically significant activation of protein kinase $C$ at $P<0.005$ using a one-tailed $t$-test with Bonferroni correction for multiple comparisons.

* No detectable protein kinase $\mathrm{C}$ activity.

particularly significant considering the concentrations found in patients exposed to the toxin. Lead has no known biological value, so its optimal concentration in living systems is zero. Because of worldwide environmental exposure, the 'normal' blood concentration of lead is between 5 and $25 \mu \mathrm{g}$ per $100 \mathrm{ml}$ of whole blood or $10^{-6} \mathrm{M}$ (ref. 9). Relatively small increases in the blood concentration of lead $(>30 \mu \mathrm{g}$ per $100 \mathrm{ml})$ are toxic ${ }^{25}$, and variations within the accepted normal range may produce adverse neurobehavioural ${ }^{8,26}$ and growth effects ${ }^{1}$. As $95-98 \%$ of the lead is bound in red blood cells, $\sim 10^{-8} \mathrm{M}$ is present in the plasma ${ }^{27}$. If the distribution of lead between plasma and cytosol is analogous to that of calcium $(10,000: 1)$, the cytosolic concentration of lead in exposed individuals should be in the picomolar range. Therefore if a specific enzyme is a target for lead toxicity, then it must be sensitive to extremely low concentrations. To our knowledge, the stimulation of protein kinase $\mathrm{C}$ represents the first observation of a lead-induced biochemical alteration in the picomolar range. As a result of its effects on protein kinase $\mathrm{C}$, lead can potentially induce changes in both the specificity and rate of substrate phosphorylation by this enzyme. We propose that the marked sensitivity of protein kinase $C$ to lead makes this regulatory enzyme a potential mediator of lead toxicity.

We thank Dr A. Lorris Betz for reviewing this manuscript. This work was supported by the National Institutes of Health.

\section{Received 24 February; accepted 18 May 1988}

1. Schwartz, J., Angle, C. \& Pitcher, H. Pediatrics 77, 281-288 (1986)

2. Pounds, J. G. Neurotoxicology 5, 295-332 (1984)

3. Simons, T. J. B. Br. med. Bull. 42, 431-434 (1986).

4. Habermann, E., Crowell, K. \& Janicki, P. Archs Toxicol 54, 61-70 (1983).

5. Landrigan, P. J. \& Graef, J. W. Pediatrics 79, 582-583 (1987).

6. Klein, R. Adv. Pediatr. 24, 103-132 (1977).

Needleman, H. L. et al. New Engl. J. Med. 300, 689-695 (1979)

Needleman, J. L. \& Landrigan, P. J. A. Rev. Public Health 2, 277-298 (1981)

9. Mahaffey, K. R., Annest, J. L. \& Roberts, J. Cew Engl. J. Med. 307, 573-579 (1982)

10. Pounds, J. G., Wright, R., Morrison, D. \& Casciano, D. A. Tox. appl. Pharmac. 63, 398-401 (1982).

11. Nishizuka, Y, Science 233, 305-312 (1986).

12. Berridge, M. J. \& Irvine, R. F. Nature 312, 315-321 (1984)

13. Takai, y et al J. biol Chem. 254, 3962-3965 (1979)

14. Castagna, M. et al. J. biol. Chem. 257, 7847-7851 (1982)

15. Worley, P. F., Baraban, J. M., De Souza, E. B. \& Snyder, S. H. Proc. natn. Acad. Sci. U.S.A $83,4053-4057$ (1986).

16. Mochly-Rosen, D., Basbaum, A. I. \& Koshland, D. E. Proc. natn. Acad. Sci. U.S.A. 84, $4660-4664$ (1987)

17. Girard, P. R. Mazzei, G. J., Wood, J. G. \& Kuo, J. F. Proc natn. Acad. Sci. U.S.A. 82 3030-3034 (1985).

18. Suszkiw, J., Toth, G., Murawsky, M. \& Cooper, G. P. Brain Res. 323, 31-46 (1984).

19. Cooper, G. P., Suszkiw, J. B. \& Manalis, R. S. Neutoloxicology 5, 247-266 (1984)

20. Inoue, M., Kishimoto, A., Takai, Y. \& Nishizuka, Y. J. biol. Chem. 252, 7610-7616 (1977).

1. Siegel, G. J., Iyengar, S. \& Fogt, S. K. J. biol. Chem. 255, 3935-3943 (1980).

22. Silbergeld, E. K., Fales, J. T. \& Goldenberg, A. M. Nature 247, 49-59 (1974).

23. Pounds, J. G., Morrison, D., Wright, R., Casciano, D. A. \& Shaddock, J. G. Tox. appl. Pharmaca. 63, 402-408 (1982).

24. Goldstein, G. W. \& Ar, D. Life Sci. 33, 101-106 (1983).

25. Lin-Fu, J. S. New Engl. J. Med. 286, 702-710 (1972).

26. Angle, C. R. \& Mclntyre, M. S. Adv. Pediatr. 29, 3-32 (1982).

27. Clarkson, T. W. \& Kench; J. E. Biochem. J. 69, 432-436 (1958)

28. Wallenstein, S., Zucker, C. L. \& Fleiss, J. L. Circulation Res. 47, 1-9 (1980).

29. Bradford, M. M. Analyt. Biochem. 72, 248-254 (1976) 